International Journal for Academic Development

Vol. X, No. X, Month 20XX, 000-000

\title{
ARTICLE
}

Communities of practice in higher education: professional learning in an academic career

Linet Arthur ${ }^{*}$

School of Education, Oxford Brookes University, Oxford, UK

School of Education, Oxford Brookes University, Harcourt Hill, Oxford OX2 9AT. Email:

larthur@brookes.ac.uk

*Email: larthur@brookes.ac.uk 


\section{Communities of practice in higher education: professional learning in an academic career}

This article focuses on the life history of a university academic, and the ways in which he learned in different communities of practice during his career. This account raises questions about the applicability of Lave and Wenger's (1991) theory to a knowledge-based organisation, and argues that both the external context and the individuals within the community impinge on learning. It suggests that the role of academic staff developers may vary depending on the CoP and should include developing networks, facilitation, providing relevant expertise, improving harmony within CoPs and harnessing the benefits of internationally dispersed CoPs.

Key words: communities of practice, higher education, situated learning

\section{Introduction}

The combination of university league tables which focus on students' teaching and learning experience and a $£ 9000$ fee for undergraduate courses has led to increased competition between universities in England and Wales and greater scrutiny of academics' ability to deliver high quality teaching. In this context, the professional learning of lecturers is of greater importance, particularly the ways in which academics develop their skills throughout their careers in higher education. Communities of practice play an important role in such academic development (Churchman, 2005; Jawitz, 2009; Viskovic, 2006; Warhurst, 2008).

For university staff developers, the theory of situated learning in communities of practice (CoPs) presents a dilemma: if CoPs are self-defining and self-developing (as situated learning theory suggests), it is not clear how external support can assist them. On the other hand, if CoPs are critical to professional development in higher education it seems important for academic staff development units to embrace this type of learning. This article uses a life-history approach to analyse one professor's learning within different communities of practice during a lengthy career in a university setting. A tentative typology is developed 
which, while acknowledging the limitations of a single life history, identifies alternative roles for academic staff developers based on different types of CoPs in universities.

\section{Defining Communities of Practice}

The concept of CoPs has been described as "shifting" (Churchman, 2005, p. 14), with evidence of some 'conceptual slippage' (Tummons, 2012) in the years since it was first described. Even at the start, Lave and Wenger's (1991, p.98) definition of a CoP was somewhat vague: 'a set of relations among persons, activity and world, over time and in relation to other tangential and overlapping communities of practice'. The CoPs they described were tightly-knit, learning-oriented, identity-developing and focused on activity.

Wenger's subsequent work (for example, Wenger, 1998, 2010), which aimed to develop further a universally applicable theory about learning in social systems, has both illuminated and (at times) obscured the original concept. His focus in 1998 was on learning and identity and he argued that practice defined a community when groups of people are mutually engaged in a joint enterprise, with a shared repertoire (Wenger, 1998). By 2002, CoPs had become 'a practical way to frame the task of managing knowledge' (Wenger et al, 2002, p. x). With what some regarded as commercial instrumentalism (Vann and Bowker, 2001; Hughes, 2007), Wenger et al (2002) suggested that, despite being organic and self-directed, CoPs could be managed and cultivated by companies to achieve organisational goals. Instead of an individual's identity becoming aligned with his or her CoP, communities of practice became a means of connecting professional identities to the organisation's strategy. Wenger et al (2002) also introduced the new concept of a 'distributed' CoP, which involved a more loose-knit structure and widely dispersed membership. 
For the purposes of this paper I have adopted Wenger's (1998) definition of a community of practice (mutual engagement in a joint enterprise with a shared repertoire) as this seems to have the greatest resonance with subsequent literature.

\section{Critical views of communities of practice}

Research into CoPs has identified a number of shortcomings in and proposed developments of the theory. Hodkinson (2004, p. 14), for example, questioned the 'cosy, homogeneous view of communities'. Gherardi et al's (1998) research indicated that power and conflicts are an inevitable part of CoPs. According to Gee et al (1996) the apparently benign nature of the CoPs described by Lave and Wenger (1991) could mask a subtle, organisational control of staff through the internalisation and reproduction of organisational goals within CoPs. Other researchers have noted that not all CoPs are cooperative; some lack expertise; some are arrogant, dogmatic or blinkered; some are exclusive; some expect compliance (Nagy and Burch, 2009; Pemberton et al, 2007; Viskovic, 2006; Cousin and Deepwell, 2005). Wenger (2010) acknowledges that CoPs can be dysfunctional, counterproductive or harmful, but argues that this is balanced by a degree of agency and sensemaking for members and the community.

\section{Situated learning in universities}

The communities of practice from which Lave and Wenger (1991) developed their original theory were apprentice tailors in Liberia, apprentice midwives in Mexico, apprentice US Navy quartermasters, apprentice butchers in US supermarkets and non-drinking alcoholics in Alcoholics Anonymous. In all five cases, the CoP formed a cohesive group and there were well-established routes to expertise. Apart from the Navy 
quartermasters, none of the CoPs could be described as 'knowledge-intensive', that is, composed of highly qualified staff who trade in knowledge (Blackler, 1995); and in all cases, the apprentices were unskilled novices compared to the expert practitioners.

My research investigates CoPs in the university sector. There are a number of ways in which the organisations in Lave and Wenger's (1991) study differ from universities. Firstly, universities are knowledgebased. Their core competency is the production of knowledge (Brown and Duguid, 1996), including decontextualised and propositional knowledge seen as unhelpful by advocates of situated learning (Hammersley, 2005). Secondly, the amount of change experienced by universities contrasts with the relative stability of the organisations in Lave and Wenger's (1991) study. During the years since the respondent in my research became an academic, changes have included moving from an elite to a mass system (Trow, 2001); a shift from mode 1 to mode 2 knowledge, that is, from abstract theory to transdisciplinary, problem-oriented, context-based knowledge (Becher and Trowler, 2001) and a move towards greater external accountability (Hoecht, 2006). A shift to modular courses in many universities has reinforced the 'individualism' of academic teaching (Warhurst, 2008, p. 458). There has also been a proliferation of management ideologies which have restricted academics' autonomy and freedom (Douglas and Douglas, 2006), and reduced the amount of time available for collegial activities (Nagy and Burch, 2009).

These changes in universities in England and Wales have created a much more turbulent environment than that experienced by the organisations in Lave and Wenger's (1991) research. Moreover, universities' complex, diverse and loose-knit structures (Becher and Trowler, 2001) differ from the orderly and (with the exception of the non-drinking alcoholics in Alcoholics Anonymous) hierarchical nature of Lave and Wenger's (1991) organisations. Although Wenger's subsequent work (for example, 1998) includes commercial 
organisations, these too are different from universities in relation to power relationships, incentives and rewards, responsibilities and resource control (Nagy and Burch, 2009).

Roberts (2006) argues that the context within which a CoP operates is a major factor in the successful creation and transfer of knowledge. There is certainly evidence to suggest that universities today may not be hospitable environments in which CoPs can flourish (for example, Warhurst, 2008; Nagy and Burch, 2009). Communities of practice in universities appear to be more complex and varied than those in Lave and Wenger's (1991) research. Tight (2004, p. 409) observes that there is 'not a single community of practice but, rather, a series of somewhat overlapping communities of practice'. Jawitz (2009) described three different types of $\mathrm{CoP}$ in a South African university, coalescing around undergraduate teaching, postgraduate teaching and research, with cross-boundary membership. In Australia, Churchman (2005) identified a crossdepartmental CoP which developed in opposition to the corporatisation of the university.

The orderly character of Lave and Wenger's (1991) research sites might help to explain the nature of situated learning that they observed. They described the way in which newcomers were gradually assimilated into a CoP, from an initial position of 'legitimate peripheral participation' (Lave and Wenger, 1991, p.29) when the novices lacked skills and knowledge - to full membership, after they had learned the community's practices, an appropriate discourse, and the stories, artefacts, activities and knowledge that constituted the CoP. During the process of assimilation, the relationship between newcomers and old-timers was key to the former's learning. Established members of the community, as well as the peers and 'near-peers' of novices, helped to develop their skills (Lave and Wenger, 1991). 
Unlike Lave and Wenger's (1991) newcomers, university academics are likely to be well qualified on appointment, with pre-existing skills and experience. Fuller et al (2005) observed that novices such as these experience a more complex legitimate peripheral participation, acting as full members in some ways while being peripheral in others. Warhurst's (2008, p. 462) case study of 29 recent recruits in an English university found that many were 'clearly immersed in practice from the outset, with little or no time spent on the periphery of their communities.' Similarly, Viskovic's (2006, p.331) research into tertiary teachers' development in New Zealand noted that most had moved rapidly into participation: "their inbound trajectories quickly immersed them in the full demands of practice'. In Wenger et al (2002) the concept of legitimate peripheral participation as a key means of learning in CoPs had disappeared. Possibly this gradual means of learning and integration was not seen as relevant to fast-changing, market-oriented, large-scale corporations.

Paradoxically, communities of practice appear to demonstrate both change and continuity over time. They reproduce themselves through the gradual introduction and assimilation of newcomers, and they also evolve as new members join, negotiate different meanings and learn from each other. Lave and Wenger (1991) suggest that the entry of newcomers is the primary source of change in CoPs. Again, this may be linked to the types of CoPs they investigated. Fuller et al (2005) proposed that change in CoPs is not only brought about by the introduction of newcomers, but also through experts initiating change, and through external forces, such as markets, laws, new technology. Wenger et al's later (2002) conception of CoPs in corporations suggested a much looser-knit community, more open to change, knowledge exchange and learning.

The key differences identified here between CoPs in Lave and Wenger's (1991) study and universities are summarised in Table 1 below: 
Table 1. Contrasts between Lave and Wenger's (1991) CoPs and those in a university setting

$$
\begin{aligned}
& \text { CoPs studied by Lave and CoPs in a university } \\
& \text { Wenger (1991) }
\end{aligned}
$$

Type of CoP

One established CoP

Several diverse CoPs,

which may be dispersed

across universities

nationally and

internationally

Environment

Stable

Turbulent

Nature of community

Close-knit

Loosely-formed

Change

Change is assimilated Internally and externally-

internally through entry of driven change resulting in

novices: a slow

major, rapid

evolutionary process

transformations

Initial knowledge

Newcomers have a low

Newcomers have a high

level of initial knowledge

level of pre-existing

knowledge

Complex and abstract knowledge

Newcomers gradually

Newcomers have abstract

acquire complexities

understandings linked to

through practice

practice from the start 
Situated learning theory suggests that CoPs are self-developing (Lave and Wenger, 1991), removing the need for external intervention and support. There is, however, evidence of active engagement by academic staff development units with CoPs in higher education, for example, initiatives to create and develop CoPs in Australian universities (Nagy and Burch, 2009) and in English universities (Pemberton et al, 2007). Jawitz (2009) suggests academic staff developers can play an important role in the 'harmonisation' process when new academics join an existing CoP (through supporting staff as they align with and challenge CoPs), while also providing opportunities for academics to learn within CoPs rather than focusing on individuals in isolation.

Much of the extant research into CoPs in universities focuses on the community more than the individual (for example, Ng and Pemberton, 2013; Churchman, 2005), or has provided 'snapshots' of individual experiences rather than a longitudinal perspective (for example, Warhurst, 2008; Viskovic, 2006). Fuller et al (2005, p.63) acknowledge the 'significance of the developing biographies of individual workers, as members of communities of practice'. My research contributes to this aspect of situated learning theory. I investigated in depth the experience of a single academic during a lengthy university career, using the theory of situated learning in CoPs to analyse his life history. I have used the data to identify a tentative typology of CoPs to help to make sense of his experiences and hypothesise ways in which academic staff developers could support these different CoPs.

\section{Methodology}

This research study adopted the life history approach (Goodson and Sikes, 2001). By exploring in-depth the life of an individual, it is possible to gain a greater understanding of communities (Cole and Knowles, 2001), of the interplay between actor and social structure and of the effects of change over time (Miller, 2000). My 
aim was to illuminate aspects of current theories of social learning in universities. Thus life history, which can 'give a uniquely rich and subtle understanding of life situations' (Punch, 2009, p.191), was an appropriate approach to take.

Purposive sampling (Bryman, 2008) was used to select a research subject. It was important to ensure that s/he had had a lengthy and varied career, preferably in the same institution (so that learning took place within the same organisational context). The academic I chose (whom I call Michael) had joined in the mid1970s the university where he was still working at the time of the interview (a short period before he retired). He had participated in a number of different CoPs (see below for an outline of his career). Regarding ethics, he agreed to the publication of the outcomes of a 2-hour interview, with his name and the name of the university anonymised. He subsequently approved the transcript of the interview for accuracy and sanctioned the level of anonymity in this article.

Life history has been criticised for being too subjective, with results that cannot be generalised (Bryman, 2008). Any knowledge claims made from life history interviews need to reflect the 'multidimensional, complex, dynamic, intersubjective and contextual nature of human experience' (Cole and Knowles, 2001, p. 127). This is an account of one individual whose experience cannot be considered representative of all academics. Rather than make generalisations, I have sought to add to existing understandings of communities of practice theory and have developed a typology which might help to explain the lived experience of this respondent. I have identified appropriate actions for academic staff developers based on this typology, which could be relevant to others who have had similar experiences to Michael.

\section{Findings}


Michael's university career falls into three distinct phases, summarised below:

- Phase 1: lecturer. Michael joined the university (a post-1992 university in England, which I shall call 'Bridge University' henceforward) as a lecturer in a department which had expanded rapidly from two to six teaching staff. Together they developed an innovative curriculum for a new modular course.

- Phase 2: staff developer. Michael moved to the university's Staff Development Unit, where he worked on two major projects (one on teaching large classes, the other on employability) while developing teaching and learning across the university.

- Phase 3: lone scholar. Michael established an international reputation through his work on teaching and learning in Higher Education. He became a Professor of Teaching and Learning and anticipated continuing this work until his retirement. (He was 64 when I interviewed him.)

\section{Phase 1: Lecturer}

When Michael first joined Bridge University in 1975, the department consisted of two 'old-timers' - members of staff who had started in 1969 and 1972 respectively - and one more recent arrival (1974). A fifth member of staff joined at almost the same time as Michael and the sixth was already working part-time in the department and became full-time in 1976. Following one change of personnel in 1980, the six members of the department, all male, of a similar age and background, although with different interests, remained together over the next ten years and developed a strong group identity. 
Although university departments do not necessarily operate as CoPs (Mathieson, 2012), Michael's department combined the characteristics of mutual engagement, joint enterprise and a shared repertoire in relation to teaching and researching their subject. While some university departments may have distinct CoPs for teaching or research (Jawitz, 2009), the members of Michael's department shared not only their approaches to teaching, but also the development of an academic journal linked to their subject.

Michael's initial feelings as he joined the department were a sense of belonging ('I was home') and anxiety: 'I came in with some degree of uncertainty and trepidation really - whether I had anything to offer, or whether I could cut it.' For him, a seminal moment came in his first few weeks, when he volunteered to organise an activity during a residential event: 'I've got this tremendous memory of it working and it buzzing around and realising I really had something to contribute there.'

The department staff worked together on a new, modular course. 'It was an exciting time and there were five or six of us coming together to create a new subject.' The two old-timers had 'created this degree on paper and it was as if it was their degree. We had to say, "no, it's ours".' Michael did not see the old-timers as providing a model of practice: 'I felt, in a sense, their equals, even if I felt also they, one or two, had skills or knowledge I hadn't got, but also I felt I could really get in there and contribute.'

Like many academics, Michael had postgraduate qualifications and teaching experience when he joined Bridge University. Fuller et al (2005) argue that it is possible for a person's peripheral status to vary in these circumstances. In Michael's case, he seemed able to fast-track through to full membership by demonstrating appropriate skills and the ability to make a contribution. This is similar to Warhurst's (2008) and Viskovic's (2006) findings that academics spend little time on the periphery. It is, perhaps, significant 
that the existing members of the CoP were a similar age to the newcomers and, because they were embarking on a new modular course, did not have an expertise which was clearly superior to those on the periphery. In addition, the two old-timers were outnumbered by newcomers; perhaps this shifted the power balance, which implicitly in Lave and Wenger (1991) lies with the old-timers.

The CoP that Michael joined may have been in the early stages of development described by Wenger et al (2002) as 'potential' and 'coalescing', although Michael's experience did not tally with Wenger et al's (2002) description of gradual evolution and identification of shared needs in these phases. On the contrary, working out the new course together was not a harmonious experience: 'We were not all friendly to each other. We argued like hell.' At the same time, they recognised each other's strengths: 'I think we were all very strong individuals, $[\ldots]$ who in large measure learned to respect each other and to work with each other.' They shared the excitement of developing something new. 'We didn't have any textbooks to tell us how to do it ... [Instead of] established constructions of knowledge, constructions of learning, here we were making it up, in large measure, we were creating it.' Trowler and Knight (2000) suggest that new academics may have difficulties in exerting individual agency in departmental CoPs but this does not appear to have been Michael's experience. Rather than the newcomers making gradual steps towards expertise, guided (and possibly constrained) by the old-timers, this CoP seemed more egalitarian, with knowledge being co-created by all its members.

Michael talked about what motivated him: 'I would describe myself then as a sort of series of enthusiasms. And [...] if I was finding that people were interested in doing things, I was drawn to them.' It did not matter whether those who shared his interests were in his own department - he was happy to work with like-minded people across the university. This reflects the 'overlapping' CoPs in higher education 
described by Tight (2004), with the loose-knit structures of universities enabling individuals to build CoPs which extend across departments.

Michael described his department as ' like having children. [...] As the kids grow up, they get into interesting things, different things.' The image of a family reflects to some extent Lave and Wenger's (1991) description of a CoP. The 'parents' (perhaps personified by the two old-timers) establish the rules but then the 'children' (the newcomers) develop novel ways of doing things themselves. Although this may suggest a greater degree of agency for newcomers than in Lave and Wenger (1991), it implies a gradual maturing and growing independence which resonates with their theory.

\section{Phase 2: Staff developer}

After ten years in his subject department, Michael had the opportunity to work part-time in the Staff Development Unit (SDU) at Bridge University, and after six months he moved there full-time. Again, his description of the SDU matched the key characteristics of a CoP: mutual engagement, joint enterprise and a shared repertoire.

When Michael joined the SDU, there were two established members of staff already working there, one of whom had a national reputation in academic staff development. Michael regarded these 'old-timers' as 'very different role models [...] Both of them wonderful and annoying and I had to work out how to do it for myself, watching them and learning a lot.' 
Two other new staff started working at the SDU at the same time as Michael. He identified this as a positive factor, that he was learning the job alongside others. Unlike his early days in his subject department, however, there was no sense that he and the other new staff were trying to wrest control from the old-timers. Instead, he followed the lead of the established staff.

Michael's position in the SDU was similar to the process of legitimate peripheral participation. As a newcomer, his relationship to the old-timers was significant and his learning took place in a social context rather than through formal instruction: 'you worked out things that seemed to work'. Michael learned from one old-timer that 'if you could shift institutional policies, it mattered. So you tried to get involved in institutional policies'. Michael's past experience was relevant, but he needed new skills: 'it's a very different thing being a good teacher to helping others to be good teachers'. He emphasised several times that there was 'a hell of lot of learning to do' and although it was exciting, it was not easy: 'If you think teaching students is difficult, teaching bloody adults - and adults who don't always want to be there - is bloody hard'.

Michael described what he learned: a new literature, new networks, different contexts, the culture and politics of different departments, local and national opportunities, how to work at a micro-level (with staff members), at an institutional policy level, and meta-level learning, such as how to run workshops. It is interesting to compare this list with what Lave and Wenger (1991, p.95) suggest that novices learn:

who is involved; what they do; what everyday life is like; how masters talk, walk, work and generally conduct their lives; how people who are not part of the community interact with it; what other learners are doing; and what learners need to learn to become full practitioners. 
Although there are some similarities, Michael's focus was more on the practical skills and knowledge he needed to practise as a staff developer than on the culture and community of the SDU, as indicated by Lave and Wenger (1991). Possibly this type of learning is less noticeable and more likely to be absorbed unconsciously.

In a move which could have been seen as devaluing its work, the SDU was re-located into the Personnel Department, from being a semi-autonomous department in the Vice Chancellor's office. Michael decided not to go with them, but to move instead to the Education Department and focus on his research interests.

\section{Phase 3: Lone scholar}

In the Education Department, Michael spent his time researching aspects of teaching and learning in Higher Education, attending international conferences and running seminars and workshops related to his research (nationally and internationally). He no longer did much teaching, but was 'often in positions when I am speaking publicly'. He talked about his delight in becoming a professor, both for himself and for the acknowledgement of his work.

He seemed to be in what Wenger et al (2002) would describe as a 'distributed' CoP. His focus was outside the university and his role in the Education Department was somewhat peripheral. He only occasionally went into the office, and his accommodation at the Department was changed from a large room to a desk in an office shared by visiting professors. His main links were with other researchers, located in universities around the world, working on similar areas of interest. It was a loose-knit CoP, with limited 
mutual engagement, an enterprise which was 'joint' only to the extent that its meaning was debated in academic conferences, and a shared repertoire in the sense that members of the community discussed and critically analysed their research approaches when together, and through journal articles and books.

This particular group of academics drawn from several universities has been identified as a CoP by Tight (2008), who has analysed co-citations to produce an international map of higher education research, with two distinct clusters of activity, one around structure/organisation and the other teaching/learning. These could tentatively be called discrete CoPs (Tight, 2008), with Michael belonging to the one centred around teaching and learning.

Lave and Wenger (1991) do not discuss communities of practice which are as loosely formed as this one, although Wenger et al (2002) and others (for example, Warhurst, 2008; Tummons, 2012) have described similarly dispersed communities. Hodkinson and Hodkinson (2004) suggest that the term 'communities of practice' should be preserved for the more cohesive groupings. Michael's entry into the network of teaching and learning scholars appeared to have been unproblematic. Possibly, with high levels of mutually recognised expertise, legitimate peripheral participation becomes an anomaly.

\section{Discussion}

It would be inappropriate to read too much into a single life history and to make generalisations from one individual case. Nevertheless, Michael's experience helps to shed light on aspects of the theory of situated learning and its application to a knowledge-based organisation. The importance of CoPs is evident in the imagery of a family that Michael uses to portray his feelings about his subject department. Michael's description of joining the SDU is similar to the process of legitimate peripheral participation, when old-timers 
are crucial for the learning and integration of newcomers. In the final phase of Michael's career, his learning takes place in a distributed CoP through mutual sharing and challenge with other experts in the field.

Throughout it is evident that individual personalities, context and power relationships played an important role in the development of the CoPs to which Michael belonged. What appears to have made most difference in Michael's experience, however, is the relative expertise of newcomers and old-timers in relation to the focus of the $\mathrm{CoP}$ (which may be different from their existing expertise). I have developed a tentative typology based on the three CoPs that Michael described, together with the findings of the literature review (see Table 2 below).

Table 2. Typology of university CoPs based on the life history of an academic (possible activities for academic staff developers in italics)

\begin{tabular}{|c|c|c|c|}
\hline Old timers' skills & High & $\begin{array}{l}\text { Traditional CoP: newcomers learn } \\
\text { through legitimate peripheral } \\
\text { participation. } \\
\text { Need for support to newcomers and } \\
\text { sensitivity to learning within the } \\
\text { CoP. }\end{array}$ & $\begin{array}{l}\text { Distributed CoP: rapid acceptance } \\
\text { and shared learning. } \\
\text { Need to harness the outcomes of the } \\
\text { CoP in ways that benefit the } \\
\text { university. }\end{array}$ \\
\hline $\begin{array}{l}\text { relevant to the } \\
\text { CoP }\end{array}$ & Low & $\begin{array}{l}\text { Emerging CoP: members establish } \\
\text { a new CoP. } \\
\text { Need to provide networking } \\
\text { opportunities, facilitation and } \\
\text { relevant expertise. }\end{array}$ & $\begin{array}{l}\text { Challenged CoP: newcomers bring } \\
\text { challenges which result in swift } \\
\text { development. } \\
\text { Need to focus on harmonization } \\
\text { processes. }\end{array}$ \\
\hline
\end{tabular}




\begin{tabular}{|l|c|c|c|}
\hline \multirow{2}{*}{} & \multirow{2}{*}{} & & \\
\hline \multirow{2}{*}{} & Low & High \\
\hline & \multicolumn{2}{|c|}{ Newcomers' skills relevant to the CoP } \\
\hline
\end{tabular}

The typology consists of four potential scenarios:

(1) Traditional CoP in which newcomers have low levels of expertise compared to the old-timers and learn through legitimate peripheral participation. In this case academic staff developers could play a role in supporting new academics while recognising the importance of their gradual development within the CoP.

(2) Emerging CoP, in which newcomers and old-timers both have low levels of expertise. Academic staff developers could provide relevant training opportunities for skills development and facilitation to assist the establishment of the CoP. Offering networking opportunities to encourage the initiation of new CoPs also seems an obvious role for academic staff developers.

(3) Distributed CoP, in which newcomers and old-timers both have high levels of expertise. The role for academic staff developers in these circumstances could focus on harnessing the outcomes of the CoP for the benefit of the university - otherwise there is a danger that 'lone scholars' become increasingly peripheral to their own institution.

(4) Challenged CoP, in which a newcomer's expertise is higher than that of the old-timers. This type of CoP did not emerge from Michael's experience but is described by Jawitz (2009) with a 
recommendation that, through 'harmonization', academic staff developers support new academics in challenging the status quo and the CoP in responding to those challenges.

\section{Conclusion}

My research, although limited to one interview with a single subject, indicates that the interactions within CoPs may vary depending particularly on the comparative levels of newcomers' and old-timers' skills, experience and qualifications; but also on the personalities of the participants and the context within which the $\mathrm{CoP}$ is located. While further research is needed in this area, I would hypothesise, based on my tentative typology, that appropriate action for academic staff developers varies, depending on whether the CoP is 'traditional', 'emerging', 'distributed' or 'challenged'. Their role may be to help establish networks within universities from which a variety of CoPs could develop, to offer to facilitate emergent CoPs if needed (while ensuring that members retain power over the direction of the CoP), to harness research and development opportunities within distributed CoPs and to help harmonise CoPs going through change and challenge.

\section{Notes on contributors}

Dr Linet Arthur is a Programme Lead for Student Experience at Oxford Brookes University. She co-leads the Doctorate in Education and the Leadership and Management pathway for the MA in Education. Her research interests include student evaluations of lecturers, mergers in higher education, continuing professional development and performance management in schools and universities. 


\section{References}

Becher, T. \& Trowler, P. (2001). Academic tribes and territories, $2^{\text {nd }}$ edition. Buckingham: Open University Press.

Blackler, F. (1995). Knowledge, knowledge work and organizations: an overview and interpretation. Organization Studies, 16(6), 1021-1046

Brown, J.S. and Duguid, P. (1996) Organizational learning and communities-of-practice: toward a unified view of working, learning and innovation. In M.D.Cohen \& L.S.Sproull (Eds), Organizational learning (pp. 58-82). Thousand Oaks, CA: Sage.

Bryman, A. (2008). Social Research Methods ( $3^{\text {rd }}$ edn). Oxford: Oxford University Press.

Churchman, D. (2005). Safeguarding academic communities: Retaining

texture and passion in the academy. In P. Carden and T. Stehlik (Eds).

Beyond communities of practice: Theory as experience (pp. 11-30), Queensland: Post Pressed.

Cole, A. \& Knowles, J. (Eds). (2001). Lives in Context. The Art of Life History Research. Oxford: Altamira Press.

Cousin, G. \& Deepwell, F. (2005). Designs for network learning: a communities of practice perspective. Studies in Higher Education, 30(1), 57-66

Douglas,J. \& Douglas,A. (2006). Evaluating Teaching Quality. Quality in Higher Education, 12(1), 3-13

Fuller, A., Hodkinson, H., Hodkinson, P. \& Unwin, L. (2005). Learning as peripheral participation in communities of practice: a reassessment of key concepts in workplace learning. British Educational Research Journal, 31(1), 49-68

Gee, J.P., Hull, G. \& Lankshear, C. (1996). The new work order: behind the language of the new capitalism. St Leonards: Allen and Unwin.

Gherardi, S., Nicolini, D. \& Odella, F. (1998). Towards a social understanding of how people learn in organisations. Management Learning, 29(3), 273-297

Goodson, I. \& Sikes, P. (2001). Life History Research in Educational Settings—Learning From Lives. Buckingham: Open University Press.

Gray, H. (Ed). (1999). Universities and the creation of wealth. Buckingham, SRHE \& Open University Press.

Hammersley, M. (2005). What can the literature on communities of practice tell us about educational research? Reflections on some recent proposals. International Journal of Research and Method in Education, 28(1), 5-21 
Hodkinson, H. \& Hodkinson, P. (2004). Rethinking the concept of community of practice in relation to schoolteachers' workplace learning. International Journal of Training and Development, 8(1), 21-31

Hodkinson, P. (2004). Research as a form of work: expertise, community and methodological objectivity. British Educational Research Journal, 30(1), 9-26.

Hoecht, A. (2006). Quality Assurance in UK Higher Education: Issues of Trust, Control, Professional Autonomy and Accountability. Higher Education, 51(4), 541-563

Hughes, J. (2007). Lost in translation: the journey from academic model to practitioner tool. In J. Hughes, N. Jewson \& L. Unwin (Eds), Communities of Practice: Critical Perspectives (pp. 30-40). London: Routledge.

Jawitz, J. (2009). Learning in the academic workplace: the harmonization of the collective and the individual habitus. Studies in Higher Education, 34(6), 601-614

Lave, J. (1993). The practice of learning. In S. Chaiklin \& J. Lave (Eds), Understanding practice: perspectives on activity and contexts (pp. 3-32). Cambridge UK: Cambridge University Press.

Lave, J. (1996). Teaching, as learning, in practice. Mind, Culture and Activity, 3(3), 149-164

Lave, J. \& Wenger, E. (1991). Situated learning: legitimate peripheral participation. Cambridge UK: Cambridge University Press.

Mathieson, S. (2012). Disciplinary cultures of teaching and learning as socially situated practice: rethinking the space between social constructivism and epistemological essentialism from the South African experience. Higher Education, 63(5), 549-564

Miller, R. (2000). Researching Life Stories and Family Histories. London: Sage.

Nagy, J. \& Burch, T. (2009). Communities of Practice in Academe (CoP-iA understanding academic work practices to enable knowledge building capacities in corporate universities. Oxford Review of Education, 35(2), 227-247

Ng, L.L. \& Pemberton, J. (2013). Research-based communities of practice in UK higher education. Studies in Higher Education, 38(10), 1522-1539

Pemberton, J., Mavin, S. \& Stalker, B. (2007). Scratching beneath the surface of communities of (mal) practice. The Learning Organization: The International Journal of Knowledge and Organizational Learning Management, 14(1), 62-73

Punch, K.F. (2009). Introduction to Research Methods in Education. London: Sage.

Roberts, J. (2006). Limits to Communities of Practice. Journal of Management Studies, 43(3), 623-639 
Tight, M. (2004). Research into higher education: an a-theoretical community of practice. Higher Education Research and Development, 23(4), 395-411

Tight, M. (2008). Higher education research as tribe, territory and/or community: a co-citation analysis. Higher Education, 55(5), 593-605

Trow, M. (2001). From Mass Higher Education to Universal Access. In P.G. Altbach, P.J.Gumport \& D.B.Johnstone (Eds), In Defense of American Higher Education (pp. 110-143). Baltimore MD: Johns Hopkins University Press.

Trowler, P. \& Knight, P. (2000). Coming to know in HE: theorizing faculty entry to new work contexts. Higher Education Research and Development, 19(1), 27-42

Tummons, J. (2012). Theoretical trajectories within communities of practice in higher education research, Higher Education Research and Development, 31(3), 299-310

Vann, K. \& Bowker, G. (2001). Instrumentalizing the Truth of Practice. Social Epistemology, 15(3), 247-262

Viskovic, A. (2006). Becoming a tertiary teacher: learning in communities of practice. Higher Education Research and Development, 25(4), 323-339

Warhurst, R. P. (2008). 'Cigars on the flight-desk': new lecturers' participatory learning within workplace communities of practice. Studies in Higher Education, 33(4), 453-467

Wenger, E. (1998). Communities of practice: learning, meaning and identity. Cambridge UK: Cambridge University Press.

Wenger, E. (2010). Communities of practice and social learning systems: the career of a concept. In C. Blackmore (ed). Social Learning Systems and Communities of Practice (pp. 179-198). Milton Keynes: Springer Verlag and the Open University, 179-198

Wenger, E., McDermott, R., Snyder, W. (2002). Cultivating Communities of Practice. Boston MA: Harvard Business School Press. 